Article

\title{
Soil Quality of Abandoned Agricultural Terraces Managed with Prescribed Fires and Livestock in the Municipality of Capafonts, Catalonia, Spain (2000-2017)
}

\author{
Xavier Úbeda ${ }^{1, *}$, Meritxell Alcañiz ${ }^{1}$, Gonzalo Borges ${ }^{1}$, Luis Outeiro ${ }^{2}$ and Marcos Francos ${ }^{3}$ \\ 1 Department of Geography, University of Barcelona, Montealegre 6, 08001 Barcelona, Spain; \\ meritxellalpu@gmail.com (M.A.); gonzaloborgespereira@gmail.com (G.B.) \\ 2 Department of Applied Economy, Universidad de Santiago de Compostela, \\ 15705 Santiago de Compostela, Spain; louteiro@gmail.com \\ 3 Departamento de Ciencias Históricas y Geográficas, Universidad de Tarapacá, 18 de Septiembre, 2222, \\ Arica 1010069, Chile; marcosfrancos91@gmail.com \\ * Correspondence: xubeda@ub.edu; Tel.: +34-93-403-7892
}

Received: 14 May 2019; Accepted: 21 June 2019; Published: 25 June 2019

\begin{abstract}
The abandonment of the economic activities of agriculture, livestock, and forestry since the second half of the 20th century, in conjunction with the exodus of inhabitants from rural areas, has resulted in an increase in the forest mass as well as an expansion of forest areas. This, in turn, has led to a greater risk of forest fires and an increase in the intensity and severity of these fires. Moreover, these forest masses represent a fire hazard to adjacent urban areas, which is a problem illustrated here by the village of Capafonts, whose former agricultural terraces have been invaded by shrubs, and which in the event of fire runs the risk of aiding the propagation of the flames from the forest to the village's homes. One of the tools available to reduce the amount of fuel in zones adjoining inhabited areas is prescribed burns. The local authorities have also promoted measures to convert these terraces into pasture; in this way, the grazing of livestock (in this particular instance, goats) aims to keep fuel levels low and thus reduce the risk of fire. The use of prescribed fires is controversial, as they are believed to be highly aggressive for the soil, and little is known about their long-term effects. The alternation of the two strategies is more acceptable-that is, the use of prescribed burning followed by the grazing of livestock. Yet, similarly little is known about the effects of this management sequence on the soil. As such, this study seeks to examine the impact of the management of the abandoned terraces of Capafonts by means of two prescribed fires (2000 and 2002), which were designed specifically to prevent forest fires from reaching the village. Following these two prescribed burns, a herd of goats began to graze these terraces in 2005. Here, we report the results of soil analyses conducted during this period of years up to and including 2017. A plot comprising 30 sampling points was established on one of the terraces and used to monitor its main soil quality properties. The data were subject to statistical tests to determine whether the recorded changes were significant. The results show modifications to the concentration of soil elements, and since the first prescribed burn, these changes have all been statistically significant. We compare our results with those reported in other studies that evaluate optimum soil concentrations for the adequate growth of grazing to feed goats, and conclude that the soil conditions on the terrace after 17 years are optimum for livestock use.
\end{abstract}

Keywords: grassland; rural abandonment; goats; soil nutrients; fire risk 


\section{Introduction}

Fire is a widespread phenomenon throughout our planet, and moreover, it is an ecological factor in many ecosystems [1]. In the ecosystem of the Mediterranean basin, the role played by fire is especially important given the region's climate and the inflammable nature of its vegetation. Indeed, some Mediterranean plants have developed reproduction strategies that are dependent on fire. This explains why some Mediterranean fires should be considered part of the natural process [2]. However, today, forest fires present themselves as a problem due to the socioeconomic changes suffered by the region, primarily those associated with the depopulation of rural areas and the abandonment of the silvoagricultural economy over recent decades [3]. Forests have replaced what used to be agricultural fields, increasing plant cover and the spatial continuity of the vegetation, and as a result modifying the fire regime and increasing the risk of forest fires [4]. In short, the accumulation of fuel in Mediterranean forests has become a significant environmental problem [5].

Since the beginning of the 21st century, there has been a need to manage the landscape to avoid large forest fires and minimize their impact at all levels [6]. In this regard, fire management strategies can reduce the fuel load of forests [7]. Two such strategies, prescribed fires (PFs) and prescribed grazing, allow these objectives to be achieved without them having dramatic consequences for the environment. In Catalonia, PFs have been widely employed since 1999; the aims are diverse and dependent on the type of landscape requiring management. Usually, however, the aim has been to reduce the accumulation of fuel in the forest due to the abandonment of forestry, agricultural, and livestock activities over the preceding century [8]. Additionally, the effects of the wind, in combination with certain plant diseases, have led to the accumulation of dead wood in forest areas [9]. In Catalonia, the team responsible for implementing this particular management strategy is the Forest Action Support Group (GRAF in its Catalan acronym), which is part of the Catalan Government's body of firefighters.

A further objective of PFs is the need to reduce fuel loads that have accumulated around inhabited nuclei, especially on former agricultural terraces in the immediate vicinity of villages or towns. Here, the aim is to ensure that the wildfire does not reach the village by eliminating the fuel that can help propagate the fire from the forest to the houses, that is, by creating a firebreak [10].

As stressed above, the abandonment of livestock farming in rural areas has been widespread in many countries. However, these earlier livestock practices served as an efficient control mechanism, as grazing animals not only consumed the vegetation, they also trampled down grasses and plants. In recent years, government agencies have sought to encourage new generations to return to livestock farming — not always, but sometimes, by offering financial aid—for reasons of fire prevention (one such association is known as Ramats al Bosc [11]).

As PFs have become more commonplace, their potential effects on a soil's physical, chemical, and biological properties have been widely studied (for a review, see [12]). These effects, in common with those of wildfires, depend on a range of factors and combinations of variables that include fire intensity, soil type, vegetation, land use, and a site's recent management history [13]. Moreover, in the specific case of wildfires, volatilization and the addition of elements, in part due to ash, are important for understanding changes in soil composition [14]. In short, the literature reports a broad range of effects-although not necessarily negative-on the physical, chemical, and biological properties of a soil [12].

Despite the research conducted to date, some questions have yet to be fully addressed. For example, how often can a PF be set in a given ecosystem without causing irreparable damage to its soil parameters? Does the alternation of PF and livestock grazing constitute an effective sequence for managing areas of grazing?

Landscape managers, researchers, and even the public fail to agree on the right frequency of PFs and whether, indeed, this practice is the best management tool that can be applied [15]. Alternatives, most notably mechanical management employing heavy machinery, are expensive, and forest owners are usually unwilling to spend money if they have no guarantee that they can ultimately make a profit. 
Here, to understand the scale of the problem, it should be born in mind that in Catalonia, $65 \%$ of the territory is forest, and $80 \%$ of the property is under private ownership.

The reintroduction of livestock into rural areas has been seen as a natural way to manage the accumulation of forest fuel [16]. In this regard, many actions have been promoted in Catalonia seeking the repopulation of sparsely inhabited areas-including, for example, the opening of a center to train shepherds and the provision of a government subsidy to purchase cattle-while initiatives have been taken to promote rural economies and recover and manage abandoned agricultural terraces and scrubland.

The impact of livestock farming on soils has been quite widely studied in Spain's dehesa ecosystems-that is, extensive grassland areas on which large ruminants (primarily, cattle) and pigs are set to feed [17]. More specifically, these studies have examined the impact of trampling on the soil's physical parameters: i.e., compaction, hydrophobicity, bulk density, and erosion problems associated with these surface changes. However, few studies to date have examined the impact of small ruminants—sheep and goats—on a soil's chemical properties. Here, we go some way to rectifying this by identifying the consequences of the reintroduction of livestock on the soil characteristics of the abandoned terraces of the village of Capafonts in a long-term study that spans a period of 17 years.

Capafonts has undergone a process of rural abandonment, its population falling from 400 at the beginning of the 20th century to 100 by the end [18]. This was accompanied by a shift in the predominant economic sector in which its inhabitants were employed, with the primary sector (agriculture-livestock-forestry) losing importance to the tertiary (services, primarily rural tourism) [19]. These social changes have been accompanied by a negative impact on the local environment: the forests have expanded and the tree density has increased, above all, with the abandonment of the terraces on which the almond trees were tended [20].

The village of Capafonts stands on a hill and was formerly surrounded by agricultural terraces. However, today, these have been abandoned to herbs and bushes. The vegetation that now surrounds the village makes it highly vulnerable to fire. Indeed, a wildfire in the forests of the Prades Mountains could easily be propagated to the village as a result of the inflammable vegetation on the terraces (Figure 1). In 2000, to eliminate this risk, firefighters set a PF to burn the vegetation on these terraces and create a firebreak around Capafonts. A second PF was set two years later, in 2002. Since that date, no more interventions have been taken on these terraces.
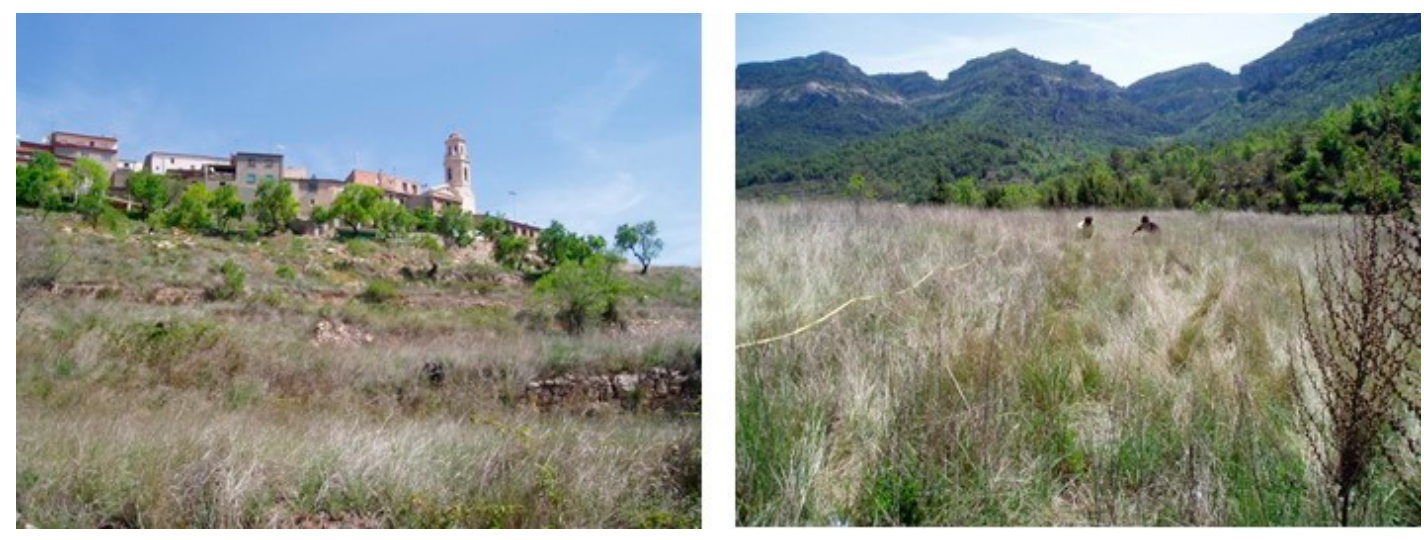

Figure 1. Photographs of the abandoned terraces and the village of Capafonts and of our study plot with the Prades mountains in the background (2017).

However, the beginning of the 21st century has seen the emergence of a new social and demographic phenomenon: that of, deurbanization or neo-ruralization, in which the urban population has begun to move back to the rural world [21]. Young entrepreneurs believe that the rural world provides opportunities for them to change their lifestyle and put their business ideas into practice. For example, in Capafonts, a young family set up home in the village and began farming goats to make cheese-and 
significantly, for our study here, the livestock began to graze on the terraces of the former almond groves, which had finally been abandoned in 2004.

The new farmers do not own these terraces, but there are no restrictions on their using them for grazing. Indeed, the original owners appear to have lost any interest in staking claim to them many years ago. In recent years, this farming family has bought various hectares of forest to convert into grazing land for their animals. As a result, the current land use of these terraces is grass pasture.

This study provides novel information about the use of PFs as a long-term management tool. The use of this type of management practice combined with controlled grazing is common in Mediterranean forest environments, such as those found in Catalonia, but few studies of their impact have been carried out to date, and so, few details are available about their effects. The specific objective of this study is to determine the soil conditions on these abandoned terraces after 17 years of fire management-which was designed to create a firebreak around Capafonts-and after more than a decade of goat herding; as such, it represents a significant advance in studies of this type.

\section{Materials and Methods}

Capafonts, a municipality in the province of Tarragona (NE Spain), provides a classic example of rural abandonment that was initiated in the final decades of the 20th century, a process not unlike that which affected many towns and villages in the developed world. The traditional forestry practices involving the extraction of wood and charcoal from the oak woodlands were discontinued, and the farmers gradually abandoned their rain-fed crops and livestock grazing (primarily, goats in this area).

The municipality of Capafonts lies in the Prades Mountains in the province of Tarragona (NE Iberian Peninsula). It has a population of 102 inhabitants (2017) and occupies an area of $13.27 \mathrm{~km}^{2}$. Our study plot is at an altitude of $740 \mathrm{~m}$ a.s.l. and was burnt for the first time on 25 February 2000.

Capafonts has an average annual rainfall of $712 \mathrm{~mm}$, with autumn and spring maxima, and an average annual temperature of $12{ }^{\circ} \mathrm{C}$. The substrate is calcareous and the soil is Xerorthents [22]. Until the first half of the 20th century, the municipality's terraces were planted with almond trees. Following their abandonment, the vegetation that emerged was a grass species (Brachypodium phoenicoides L.), which reached heights of around one meter. The plant cover was homogeneous and quite dense, and represented a considerable fire risk, as it could serve to propagate flames from the forest to the village.

The physical characteristics of the soil in terms of its particle sizes are as follows: $34.14 \%$ sands, $31.84 \%$ silt, and $34.02 \%$ clays, with $53.6 \%$ of the soil comprising coarse elements ( $>2 \mathrm{~mm}$ ).

The sampling design was based on a $4 \mathrm{~m} \times 18 \mathrm{~m}$ grid, with 30 sampling points set at 2-m intervals. This experimental design without replicates, including that of the control area, was previously used and described by Francos et al. [9] and Alcañiz et al. [15]. The large number of samples taken at each sampling ensures the reliability of our statistical outcomes. Sampling was conducted before and just after the prescribed fire. An additional sampling was completed one year after the prescribed fire of 2000. A second prescribed fire was set in 2002 two years after the first PF. We sampled the soil to determine the impact of repeating the fire management exercise. In 2004, four years after, another sampling was conducted to determine the changes that had taken place in the soil and, from that year onwards, a herd of goats was set to graze on this plot. A final sampling was conducted in 2017, 17 years after the first prescribed fire.

The sampling design used in this study is the same as that described for the Montgrí plot (see [15]). Soil samples were taken from the top layer $(0-5 \mathrm{~cm})$ at each of the 30 sampling points using a small pick. Then, ash was removed, and the sample was air dried in the laboratory and sieved to obtain a $<2 \mathrm{~mm}$ fraction. Soil $\mathrm{pH}$ [1:2.5] was analyzed following extraction with deionized water and measured with a pH meter [23]. Soil organic carbon (OC) was measured using the loss-on-ignition (LOI) method described in [24]. Total N was determined by elemental analysis (NaA2100 Protein Nitrogen Analyser). Available P was analyzed using the Olsen Gray method [25]. Exchangeable cations, $\mathrm{Ca}^{2+}, \mathrm{Mg}^{2+}$, 
and $\mathrm{K}^{+}$were analyzed by ammonium acetate extraction [26] and determined by atomic absorption spectrophotometry. $\mathrm{CaCO}_{3}$ was analyzed with a Bernard calcimeter.

Before conducting the statistical analyses, data normality and homogeneity were checked using a Shapiro-Wilk and Levene test. All the data followed a Gaussian distribution and presented homogeneity of variance. Thus, we applied a one-way ANOVA test, and significant differences were identified at $p<0.05$. Tukey's post-hoc test identified significant differences between sampling moments. A redundancy analysis (RDA) was carried out to identify the variations between the different sampling moments. The soil properties included were $\mathrm{pH}, \mathrm{OC}, \mathrm{N}, \mathrm{Ca}^{2+}, \mathrm{Mg}^{2+}, \mathrm{K}^{+}$, and $\mathrm{CaCO}_{3}$. These analyses were carried out using SPSS 20.0 and Canoco for Windows 4.5.

\section{Results}

We show the soil chemical results from the six sampling periods in Table 1, and also report statistically significant increases or decreases in these properties by means of the $p$-values from a one-way ANOVA.

Almost all the soil parameters analyzed here increased after the first PF; however, a year later, these values had fallen. The second PF caused slight increases in soil calcium, magnesium, potassium, and phosphorus, but organic carbon and nitrogen levels did not rise. At the end of the study in 2017, there was considerable variation in the soil parameters compared to their initial values, and our objective here is to determine (see Section 4.6 for details) whether the soil quality is optimal for sustaining grazing.

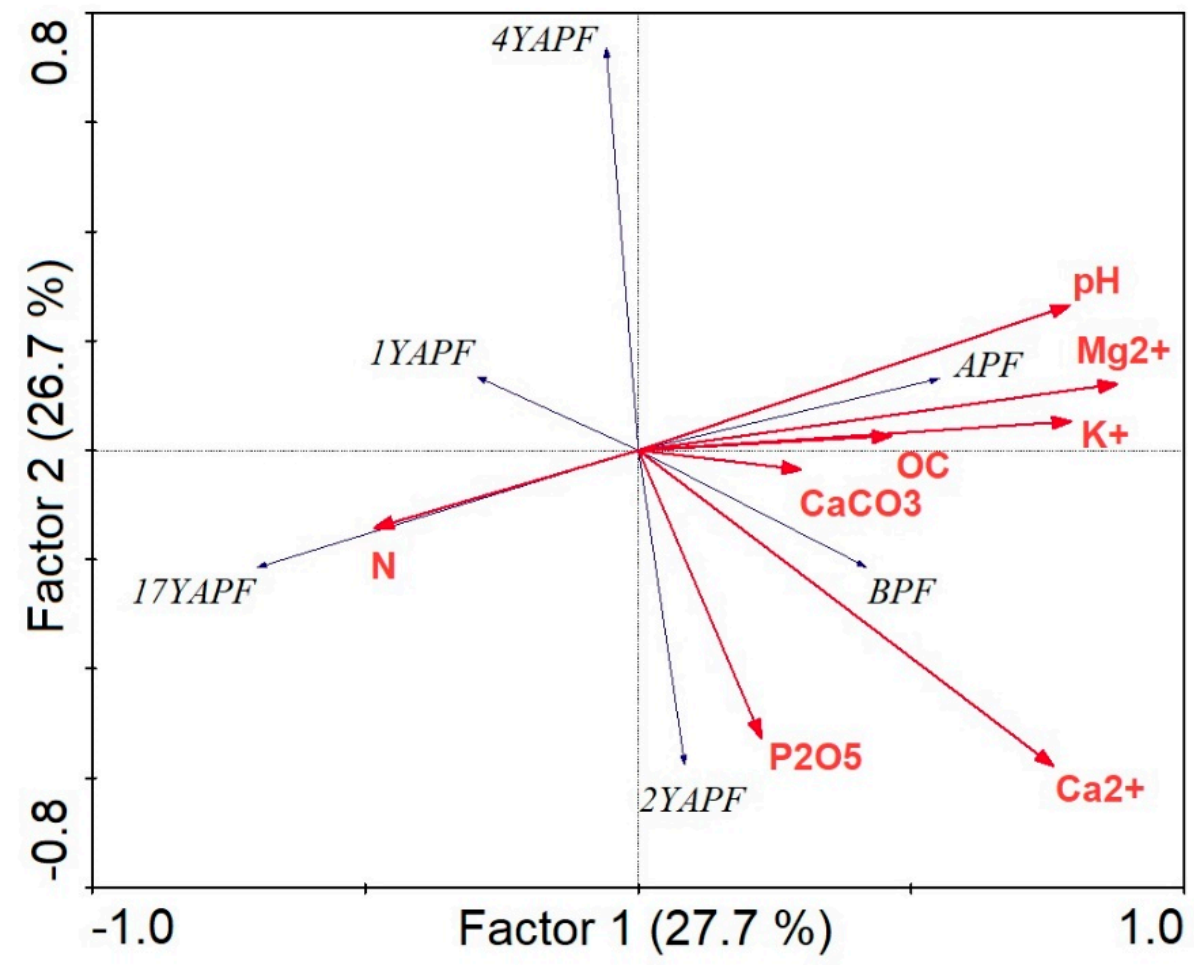

Figure 2. Redundancy analysis (RDA) showing the relation between factors 1 and 2. $\mathrm{pH}$, organic carbon $(\mathrm{OC})$, nitrogen $(\mathrm{N}), \mathrm{Ca}^{2+}, \mathrm{Mg}^{2+}, \mathrm{K}^{+}, \mathrm{P}_{2} \mathrm{O}_{5}$ and $\mathrm{CaCO}_{3}$. Before the prescribed fire (BPF), after the prescribed fire (APF), one year after the prescribed fire (1YAPF), two years after the prescribed fire (2YAPF), four years after the prescribed fire (4YAPF), and 17 years after the prescribed fire (17YAPF) 
Table 1. Minimum, maximum, mean (in bold), Prescribed Fire (PF), standard deviation (SD), variance, and standard error (SE) values before the prescribed fire (BPF), after the prescribed fire (APF), one year after the prescribed fire (1YAPF), two years after the prescribed fire (2YAPF), four years after the prescribed fire (4YAPF), and 17 years after the prescribed fire (17YAPF). Different letters represent significant differences at a $p<0.05$. ${ }^{*} p<0.05,{ }^{* *} p<0.01,{ }^{* * *} p<0.001 . N=30$.

\begin{tabular}{|c|c|c|c|c|c|c|c|}
\hline $\begin{array}{c}\text { Soil } \\
\text { Properties }\end{array}$ & Statistics & Before PF & After PF & 1 Year & $\begin{array}{c}2 \text { Years and } \\
\text { Immediately } \\
\text { after Second PF }\end{array}$ & $\begin{array}{l}4 \text { Years Goats } \\
\text { Introduced }\end{array}$ & 17 Years \\
\hline \multirow{6}{*}{$\mathrm{pH}$} & Min & 7.37 & 7.73 & 7.63 & 7.60 & 7.29 & 7.07 \\
\hline & Max & 8.11 & 8.23 & 7.91 & 7.79 & 8.24 & 7.63 \\
\hline & Mean & 7.83 & 8.00 & 7.77 & 7.71 & 7.76 & 7.37 \\
\hline & $\mathrm{SD}$ & 0.14 & 0.13 & 0.07 & 0.05 & 0.18 & 0.13 \\
\hline & Variance & 0.02 & 0.02 & 0.01 & 0.00 & 0.03 & 0.02 \\
\hline & $* * *$ & $\mathrm{~b}$ & a & $\mathrm{bc}$ & c & $\mathrm{bc}$ & d \\
\hline \multirow{6}{*}{ OC (\%) } & Min & 3.55 & 4.32 & 6.54 & 7.77 & 4,54 & 1.10 \\
\hline & Max & 21.98 & 24.74 & 14.18 & 12.17 & 12.98 & 12.51 \\
\hline & Mean & 10.32 & 11.53 & 11.42 & 10.09 & 8.56 & 5.39 \\
\hline & $\mathrm{SD}$ & 4.56 & 4.04 & 1.70 & 1.10 & 2.00 & 2.85 \\
\hline & Variance & 20.76 & 16.34 & 2.90 & 1.21 & 3.76 & 8.13 \\
\hline & $* * *$ & $\mathrm{ab}$ & a & $\mathrm{a}$ & $\mathrm{ab}$ & $\mathrm{b}$ & c \\
\hline \multirow{6}{*}{$\mathrm{N}(\%)$} & Min & 0.26 & 0.32 & 0.29 & 0.23 & 0.20 & 0.32 \\
\hline & Max & 0.53 & 0.64 & 0.64 & 0.50 & 0.50 & 0.94 \\
\hline & Mean & 0.36 & 0.46 & 0.48 & 0.34 & 0.32 & 0.63 \\
\hline & $\mathrm{SD}$ & 0.08 & 0.24 & 0.11 & 0.07 & 0.08 & 0.14 \\
\hline & Variance & 0.01 & 0.06 & 0.01 & 0.00 & 0.01 & 0.02 \\
\hline & $* * *$ & c & $\mathrm{b}$ & $\mathrm{b}$ & c & c & a \\
\hline \multirow{6}{*}{$\mathrm{Ca}^{2+}(\mathrm{ppm})$} & Min & 16,710 & 13,830 & 5120 & 15,138 & 4578 & 9014 \\
\hline & Max & 29,900 & 31,280 & 13,420 & 21,731 & 9066 & 12,632 \\
\hline & Mean & 22,130 & 20,784 & 8836 & 18,179 & 6469 & 10,177 \\
\hline & SD & 4329 & 4121 & 2037 & 1668 & 869 & 790 \\
\hline & Variance & $18,748,186$ & $16,990,130$ & $4,149,975$ & $2,783,349$ & 756,751 & 625,038 \\
\hline & $* * *$ & a & a & c & b & d & c \\
\hline \multirow{6}{*}{$\mathrm{Mg}^{2+}(\mathrm{ppm})$} & Min & 614 & 960 & 320 & 533 & 474 & 325 \\
\hline & Max & 1583 & 1444 & 830 & 838 & 886 & 640 \\
\hline & Mean & 1006 & 1244 & 507 & 627 & 713 & 446 \\
\hline & SD & 254 & 139 & 130 & 67 & 78 & 73 \\
\hline & Variance & 63,476 & 19,543 & 17,043 & 4522 & 6173 & 5446 \\
\hline & $* * *$ & $\mathrm{~b}$ & $\mathrm{a}$ & d & c & $\mathrm{c}$ & d \\
\hline \multirow{6}{*}{$\mathrm{K}^{+}(\mathrm{ppm})$} & Min & 697 & 900 & 459 & 606 & 563 & 460 \\
\hline & Max & 1732 & 1816 & 928 & 1003 & 956 & 865 \\
\hline & Mean & 1132 & 1326 & 665 & 738 & 771 & 591 \\
\hline & $\mathrm{SD}$ & 319 & 246 & 134 & 95 & 96 & 98 \\
\hline & Variance & 101,881 & 60,900 & 18,183 & 9155 & 9273 & 9617 \\
\hline & $* * *$ & b & $\mathrm{a}$ & $\mathrm{cd}$ & c & $\mathrm{c}$ & d \\
\hline \multirow{6}{*}{$\mathrm{P}_{2} \mathrm{O}_{5}(\mathrm{ppm})$} & Min & 49.12 & 5.98 & 78.95 & 105.20 & 41.20 & 45.00 \\
\hline & Max & 138.01 & 245.72 & 253.16 & 320.44 & 142.54 & 143.55 \\
\hline & Mean & 84.70 & 132.24 & 137.25 & 216.53 & 65.24 & 69.61 \\
\hline & SD & 24.33 & 42.62 & 36.59 & 48.89 & 20.28 & 19.39 \\
\hline & Variance & 591.74 & 1816.65 & 1338.91 & 2390.59 & 411.39 & 375.89 \\
\hline & $* * *$ & c & b & b & a & c & c \\
\hline \multirow{6}{*}{$\mathrm{CaCO}_{3}(\%)$} & Min & 21.48 & 19.57 & 11.01 & 20.60 & 21.00 & 21.60 \\
\hline & Max & 43.61 & 32.97 & 28.76 & 30.91 & 29.05 & 29.13 \\
\hline & Mean & 28.72 & 24.34 & 20.80 & 24.28 & 25.87 & 24.54 \\
\hline & SD & 4.30 & 3.23 & 3.86 & 2.04 & 1.99 & 1.67 \\
\hline & Variance & 18.50 & 10.45 & 14.95 & 4.16 & 4.03 & 2.81 \\
\hline & $* * *$ & $\mathrm{a}$ & $\mathrm{b}$ & $\mathrm{c}$ & $\mathrm{b}$ & $\mathrm{b}$ & $\mathrm{b}$ \\
\hline
\end{tabular}

The RDA allows us to determine differences in soil properties over time. Factor 1 in the RDA explains $27.7 \%$ of the variance, and Factor 2 explains $26.7 \%$ of the variance, that is, a combined total of $54.4 \%$ of the variance. The variables with the highest explanatory capacity are $\mathrm{Ca}^{2+}, \mathrm{Mg}^{2+}$, and $\mathrm{pH}$, while those with the lowest capacity are $\mathrm{CaCO}_{3}$ and OC. The RDA clearly separates the prescribed fire events that played an important role- that is before the prescribed fire (BPF), after the prescribed fire $(\mathrm{APF})$, and two years after the prescribed fire (2YAPF)-from those that happened some time after the prescribed fire. $\mathrm{Ca}^{2+}$ could be associated with $\mathrm{BPF}, \mathrm{Mg}^{2+}, \mathrm{pH}, \mathrm{K}^{+}, \mathrm{OC}$, and $\mathrm{CaCO}_{3}$ were closely associated with $\mathrm{APF}$, and $\mathrm{P}_{2} \mathrm{O}_{5}$ was associated with $2 \mathrm{YAPF}$ (Figure 2). 


\section{Discussion}

\section{1. $p H$}

Changes in $\mathrm{pH}$ after a fire can be attributed to the oxidation of the organic matter and the incorporation of cations produced by combustion [27]. According to the literature, after a PF, different outcomes are found: some studies report no changes in the $\mathrm{pH}$ in their soils [28,29], some observe no significant changes [30], while others report an increase [31,32].

The reasons for these changes, significant or otherwise, as well as for the lack of alterations in soil $\mathrm{pH}$, after prescribed burns appear to be related to any treatments conducted prior to fuel combustion [30], and, according to Alcañiz et al. [15], the intensity at which the fire burned at the surface and in the first few centimeters of the soil layer. Various authors, including [15], stressed that the recurrence of prescribed fires at short time intervals can also have a differential impact on soil $\mathrm{pH}$. This conclusion is ratified by Muqaddas et al. [33], who reported the effects of periodic PFs with frequency regimes of two and four years over a 35-year period.

Here, we found a significant increase in $\mathrm{pH}$ after the first burn, but no significant change was recorded after the second. This behavior can be attributed to there being more fuel to burn in the first PF as different species of bush had colonized the area, whereas during the second burn, what was burnt was largely dry grasses. Moreover, in line with the findings of Muqaddas et al. [33], repeated PFs at the same site result in different impacts on a soil's chemical qualities.

Few studies have examined the $\mathrm{pH}$ changes in soils subject to grazing. However, Teague et al. [34] reported significant $\mathrm{pH}$ changes and variations depending on whether grazing is intense ('heavy continuous') or more moderate ('light continuous'). Here, we found a statistically significant decrease in $\mathrm{pH}$ values 13 years after goats were introduced (i.e., 17 years after the first PF). This decrease is not unexpected if we consider (see below for more details) that the cation levels responsible for higher $\mathrm{pH}$ values also undergo a decrease.

\subsection{Organic Carbon and Total Nitrogen}

Organic carbon (OC) is one of the most widely studied parameters in this context, given that it is critical for understanding soil quality, whether it be for forestry or agriculture [35]. Most studies report an increase in OC since with combustion, part of the organic matter that burns is partially pyrolyzed [14]. In PFs of both high and low intensity, this causes OC levels to increase [36,37]. However, in line with other parameters, the recurrence of PFs at short time intervals can reduce the magnitude of these changes [33]. Here, we found that the changes after the first PF were more noticeable than those after the second, when OC levels actually fell.

In the case of grazing, Teague et al. [34] reported that plots subject to heavy continuous grazing had the lowest levels of organic carbon. Qasim et al. [38] reviewed 12 studies from around the globe comparing non-grazed plots with those used for grazing, and reported a fall in OC levels in all cases, with just one of the studies not reporting a significance greater than 95\%. In our study, we also recorded a statistically significant decrease in OC levels 4 YAPF and the introduction of livestock grazing, which is logical if we consider that there is less vegetation after the reintroduction of goats.

Most studies reported an increase in nitrogen after a prescribed burn [15,39]; however, some did not find any significant change [40]. Úbeda et al. [10] associated this increase to the incorporation of micro ash particles produced by combustion into the soil.

In Capafonts, while there was no significant increase in nitrogen after the first PF, we did record a significant rise after the second burn. Similar responses have been recorded by both Muqaddas et al. [33] and Blankenship and Arthur [41]. In these two studies, plots were also burned every two years, suggesting that such frequent burning does not provide sufficient time for the stabilization of certain soil parameters.

In the case of grazing, some studies reported a decrease in soil nitrogen following the passage of cattle [38] compared to soils on which cattle had not been allowed to graze. However, in Capafonts, 
nitrogen increased considerably, which may be due to the type of vegetation grown on this plot. Brachypodium phoenicoides is a legume and, apart from having high nitrogen content [42], it has been shown to be a good nitrogen fixer in the soil [43].

\subsection{Cations}

Various studies indicate that PFs act to trigger a change in levels of calcium, magnesium, and potassium, as well as changes in the distribution of these cations [44]. Some report an increase after a PF [31,39], as occurred at the Capafonts plot after the first burn, although not after the second. The small quantity of ash produced by the first fire could account for this increase, while the washing or leaching of ash following the second fire might explain why cation values fell. Several studies have also examined the duration of these increases, with some reporting long-term effects [32] and others finding only very ephemeral changes [45]. Alcañiz et al. [15] found that after burning, and once the vegetation had begun to recover (after a year), there was a very significant reduction in potassium levels due to leaching and the high consumption of this cation by plants. Here, we recorded a similar trend. Overall, Alcañiz et al. [15] concluded that PFs are beneficial because they increase nutrient availability.

In line with our findings here, Teague et al. [34] found a statistically significant decrease in the content of calcium and potassium in grass grazing. These authors attribute part of the decline in these cations to erosive processes in places of heavy grazing. However, in Capafonts, the decrease must be attributable to the consumption of these cations by plants, given that our plot is a terrace, and as such provides no slope for erosive processes to occur.

\subsection{Phosphorous}

In the case of available phosphorus, we found an increase after both PFs. McKee [46] claimed that PFs accelerate the phosphorus cycle, and that in places where limited phosphorus is available, PFs can trigger levels of this nutrient. However, it is not advisable to set frequent PFs, because according to Brye [28] in the United States, annual PFs over a 12-year period significantly reduced the soil phosphorus content.

Teague et al. [34] found no changes in phosphorus levels in association with heavy or light grazing. Likewise, our data showed no statistically significant change in phosphorus content, rising only slightly from $65.24 \mathrm{mg} / \mathrm{kg}$ to $69.61 \mathrm{mg} / \mathrm{kg}$ between $2005-2017$.

However, Aarons et al. [47] and Sharpley and Moyer [48] reported an increase in assimilable phosphorus in the soil, which they attribute to cattle droppings. However, here, given that the number of goats grazing the plot was small, phosphorous levels in the soils of Capafonts did not increase following the reintroduction of livestock on the terraces.

\subsection{Calcium Carbonates}

Various studies have attributed the changes in soil $\mathrm{CaCO}_{3}$ content after a fire to the incorporation of ash. Pereira et al. [14], in studies conducted both in Portugal and Catalonia, showed how the ash resulting from a very severe combustion (white ash) contains a high percentage of $\mathrm{CaCO}_{3}$. However, here, we recorded an overall fall in $\mathrm{CaCO}_{3}$ content, which could indicate that the PFs were not severe enough to create intense burning.

In the case of grazing, $\mathrm{CaCO}_{3}$ content is typically reported as increasing. Stavi et al. [49] found that there was an increase of $\mathrm{CaCO}_{3}$ content with livestock grazing, although they detected the importance of plot orientation in relation to the predominant vegetation type. This suggests that the vegetation available to the livestock is determined by the soil's calcium carbonate content.

\subsection{Multivariable Analysis and Soil Quality in 2017}

The multivariable analysis shows that the groups of variables, and the changes in soil properties, are largely determined by the two prescribed burns, and as such, this type of management practice 
produces greater changes than those resulting from controlled grazing. This is particularly true of the first prescribed burning, around which a large number of variables are grouped.

The soil properties recorded at the Capafonts site in 2017 were compared with the reference values published in various studies conducted on soils dedicated to the cultivation of grazing to provide grazing for different types of livestock. INIA [50], Espinoza et al. [51], and Sela [52] established a range of reference values for $\mathrm{P}_{2} \mathrm{O}_{4}$ from $>30$ to $100 \mathrm{mg} / \mathrm{kg}$. The corresponding value for Capafonts stands at $69.61 \mathrm{mg} / \mathrm{kg}$, which means it lies within these limits. In the case of the cations (i.e., $\mathrm{Ca}, \mathrm{Mg}$, and $\mathrm{K}$ ) the values recorded at Capafonts (see Table 1 ) are above the minimum values specified as references by Sela [52], namely $2000 \mathrm{mg} / \mathrm{kg}$ in the case of calcium, $180 \mathrm{mg} / \mathrm{kg}$ in that of magnesium, and between $200-800 \mathrm{mg} / \mathrm{kg}$ for potassium. Espinoza et al. [51] also established an optimal percentage value for OC in soils for grazing. The minimum value of $1.16 \%$ is well below that of $5.39 \%$ recorded at Capafonts.

Therefore, we can conclude that exposure to prescribed burnings and 13 years of goat herding have not degraded the soils' chemical properties with the exception of a slight magnesium deficiency, according to the recommended limits identified by Landon [53]. However, the other references consulted do not consider this level unsuitable for grazing. Likewise, AQM [54] recommended a 1\% nitrogen level for grazing soils, while our sample has a level of $0.63 \%$, albeit that nitrogen levels at our site have increased in recent years after falling as low as $0.32 \%$ (see Table 1). Overall, the soil quality data indicated that the soil of the Capafonts plot is of optimum quality and has not suffered degradation over time.

\section{Conclusions}

Prescribed burns are a good tool for managing the accumulation of forest fuel, but repeating PFs every two years can result in soil nutrient loss.

The soil parameters analyzed herein present a normal variation if we consider their exposure to prescribed fires and goat browsing. While the changes in the soil's chemical properties are significant, this does not mean that PFs and livestock farming should be shunned. Indeed, on the basis of the data reported herein, the state of the soil today, 17 years after the first $\mathrm{PF}$, can be considered optimal.

A recommendation that could be made to GRAF firefighters when setting prescribed burns is to ensure that the fires do not acquire any great intensity, as it has been shown that high-intensity PFs reduce soil phosphorus content. Therefore, the next step is to sit the GRAF firefighters, the local council, and livestock farmers down at the same table to consider the best timing for the next PF in Capafonts.

Author Contributions: X.Ú. is the head of the research group and wrote the paper; M.A. did the fieldwork and wrote the paper; G.B. did the laboratory analysis; L.O. is the co-supervisor of M.A. PhD Thesis and did the revision of the paper; M.F. did the fieldwork and data treatment.

Funding: Spanish Ministry of Economy and Competitiveness and the European Union via European Funding for Regional Development (FEDER) CGL2013-47862-C2-1-R; CGL2016-75178-C2-2-R [AEI/FEDER, UE] and Agència de Gestió d'Ajuts Universitaris i de Recerca de la Generalitat de Catalunya 2017SGR1344.

Acknowledgments: This study was made possible thanks to Projects CGL2013-47862-C2-1-R and POSTFIRE_CARE Project (CGL2016-75178-C2-2-R [AEI/FEDER, UE]) sponsored by the Spanish Ministry of Economy and Competitiveness and the European Union via European Funding for Regional Development (FEDER). We also thank the FPU Program (FPU13/00139) promoted by the Ministry of Economy, Culture and Sports. Financial support from the Postdoctoral Program I2C, organized by the Xunta de Galicia, is gratefully acknowledged for helping in the preparation of this manuscript. We also enjoyed the benefits of grant 2017SGR1344 awarded by the Agència de Gestió $d^{\prime}$ Ajuts Universitaris $i$ de Recerca de la Generalitat de Catalunya, which served to support the activities of the research groups (SGR2017-2019). We thank the members of the GRAF team for providing support in the field and helping in completing the project. Finally, we would like to thank the Scientific and Technological Centers at the University of Barcelona (CCiTUB) for undertaking analyses of soil chemical parameters.

Conflicts of Interest: The authors declare no conflict of interest. 


\section{References}

1. Doerr, S.H.; Santín, C. Global trends in wildfire and its impacts: Perceptions versus realities in a changing world. Philos. Trans. R. Soc. B: Biol. Sci. 2016, 371, 20150345. [CrossRef] [PubMed]

2. Pausas, J.G.; Llovet, J.; Rodrigo, A.; Vallejo, R. Are wildfires a disaster in the Mediterranean basin?-A review. Int. J. Wildland Fire 2009, 17, 713-723. [CrossRef]

3. Vélez, R. La Defensa Contra Incendios Forestales: Fundamentos y Experiencias; McGraw Hill Interamericana De España S.A.U: Madrid, Spain, 2000.

4. Moreira, F.; Rego, F.C.; Ferreira, P.G. Temporal (1958-1995) pattern of change in a cultural landscape of northwestern Portugal: Implications for fire occurrence. Landsc. Ecol. 2001, 16, 557-567. [CrossRef]

5. Pausas, J.G.; Fernández-Muñoz, S. Fire regime changes in the Western Mediterranean Basin: From fuel-limited to drought-driven fire regime. Clim. Chang. 2012, 110, 215-226. [CrossRef]

6. Fernandes, P.M.; Davies, G.M.; Ascoli, D.; Fernández, C.; Moreira, F.; Rigolot, E.; Molina, D. Prescribed burning in southern Europe: Developing fire management in a dynamic landscape. Front. Ecol. Environ. 2013, 11, e4-e14. [CrossRef]

7. Verkerk, P.J.; de Arano, I.M.; Palahí, M. The bio-economy as an opportunity to tackle wildfires in Mediterranean forest ecosystems. For. Policy Econ. 2018, 86, 1-3. [CrossRef]

8. Galán, M.; Lleonart, S. Plans de gestió de grans incendis forestals. In Incendis Forestals, Dimensió Sociambiental, Gestió Del Risc i Ecologia Del Foc; Plana, E., Ed.; XCT2001-00061; Xarxa ALINFO: Solsona, Spain, 2004; pp. 50-55.

9. Francos, M.; Pereira, P.; Alcañiz, M.; Mataix-Solera, J.; Úbeda, X. Impact of an intense rainfall evento on soil properties following a wildfire in a Mediterranean environment (North-East Spain). Sci. Total Environ. 2016, 572, 1353-1362. [CrossRef] [PubMed]

10. Úbeda, X.; Lorca, M.; Outeiro, L.; Bernia, S.; Castellnou, M. Effects of prescribed fire on soil quality in Mediterranean grassland (Prades Mountains, northeast Spain). Int. J. Wildland Fire 2005, 14, 379-384. [CrossRef]

11. Available online: http://ramatsalbosc.org/ (accessed on 15 May 2019).

12. Alcañiz, M.; Outeiro, L.; Francos, M.; Úbeda, X. Effects of prescribed fires on soil properties: A review. Sci. Total Environ. 2018, 613, 944-957. [CrossRef]

13. Outerio, L.; Asperó, F.; Úbeda, X. Geostatistical methods to study spatial variability of soil cations after a prescribed fire and rainfall. Catena 2008, 74, 310-320. [CrossRef]

14. Pereira, P.; Úbeda, X.; Martin, D. Fire severity effects on ash chemical composition and water-extractable elements. Geoderma 2012, 141, 105-114. [CrossRef]

15. Alcañiz, A.; Outeiro, L.; Francos, M.; Farguell, F.; Úbeda, X. Long-term dynamics of soil chemical properties after a prescribed fire in a Mediterranean forest (Montgri Massif, Catalonia, Spain). Sci. Total Environ. 2016, 572, 1329-1335. [CrossRef]

16. Lovreglio, R.; Meddour-Sahar, O.; Leone, V. Goat grazing as a wildfire prevention tool: A basic review. iFor. Biogeosci. For. 2014, 7, 260-268. [CrossRef]

17. Pulido, M.; Schnabel, S.; Lavado Contador, J.F.; Lozano-Parra, J.; González, F. The impact of heavy grazing on soil quality and pasture production in rangelands of SW Spain. Land Degrad. Dev. 2018, 29, $219-230$. [CrossRef]

18. Institut d'Estadística de Catalunya. Available online: www.idescat.cat (accessed on 29 June 2018).

19. Capafonts Local Council. Butlletí d'informació Municipal (2011-2015); Capafonts Local Council: Capafonts, Spain, 2015; 32p.

20. FAO. State of the World's Forests; FAO: Rome, Italy, 2011; p. 179.

21. Badia, A.; Valldeperas, N. El valor histórico y estético del paisaje: Claves para entender la vulnerabilidad de la interfaz urbano-forestal frente a los incendios. Scr. Nova 2015, 19, 1-26.

22. USDA. Claves para la Taxonomía de Suelos; United States Department of Agriculture: Washington, DC, USA, 1999; p. 410.

23. MAPA (Ministerio de Agricultura Pesca y Alimentación). Métodos Oficiales de Análisis Vol III; Secretaría Técnica General: Madrid, Spain, 1996.

24. Heiri, O.; Lotter, A.F.; Lemcke, G. Loss on ignition as a method for estimating organic and carbonate content in sediments: Reproducibility and comparability of results. J. Paleolomnol. 2001, 5, 101-110. [CrossRef] 
25. Olsen, S.R.; Cole, C.V.; Frank, S.W.; Dean, L.A. Estimation of Available Phosphorus in Soils by Extraction with Sodium Bicarbonate; USDA Circular No 939; US Government Printing Office: Washington, DC, USA, 1954.

26. Knudsen, D.; Petersen, G.A. Lithium Sodium and potassium. In Methods of Soil Analysis; Soil Science Society of America: Madison, WI, USA, 1986; Volume 2, pp. 225-246.

27. Certini, G. Effects of fire on properties of forest soils: A review. Oecologia 2005, 143, 1-10. [CrossRef] [PubMed]

28. Brye, K.R. Soil physicochemical changes following 12 years of annual burning in a humid-subtropical tallgrass prairie: A hypothesis. Acta Oecol. 2006, 30, 407-413. [CrossRef]

29. Valkó, O.; Deak, B.; Magura, T.; Torok, P.; Kelemen, A.; Tóth, K.; Horvarth, R.; Nagy, D.D.; Debnar, Z.; Zsigrai, G.; et al. Supporting biodiversity by prescribed burning in grasslands-A multi-taxa approach. Sci. Total Environ. 2016, 572, 1377-1384. [CrossRef]

30. Switzer, J.M.; Hope, G.D.; Grayston, S.J.; Prescott, C.E. Changes in soil chemical and biological properties after thinning and prescribed fire for ecosystem restoration in a Rocky Mountain Douglas-fir forest. For. Ecol. Manag. 2012, 275, 1-13. [CrossRef]

31. Arocena, J.M.; Opio, C. Prescribed fire-induced changes in properties of sub-boreal forest soils. Geoderma 2003, 113, 1-16. [CrossRef]

32. Lavoie, M.; Starr, G.; Mack, M.C.; Martin, T.; Gholz, H.L. Effects of a prescribed fire on understory vegetation, carbon pools, and soil nutrients in a longleaf pine-slash pine forest in Florida. Nat. Area J. 2010, 30, 82-94. [CrossRef]

33. Muqaddas, B.; Zhou, X.; Lewis, T.; Wild, C.; Chen, C. Long-term frequent prescribed fire decreases surface soil carbon and nitrogen pools in wet sclerophyll forest of Southeast Queensland, Australia. Sci. Total Environ. 2015, 536, 39-47. [CrossRef] [PubMed]

34. Teague, W.R.; Dowhower, S.L.; Baker, S.A.; Haile, N.; DeLaune, P.B.; Conover, D.M. Grazing management impacts on vegetation, soil biota and soil chemical, physical and hydrological properties in tall grass prairie. Agric. Ecosyst. Environ. 2011, 141, 310-322. [CrossRef]

35. Gónzalez-Pérez, J.A.; González-Vila, F.J.; Almendros, G.; Knicker, H. The effects of fire on soil organic matter-A review. Environ. Int. 2004, 30, 855-870. [CrossRef] [PubMed]

36. Soto, B.; Díaz-Fierros, F. Interactions between plant ash leachates and soil. Int. J. Wildland Fire 1993, 3, 207-216. [CrossRef]

37. Scharenbroch, B.C.; Nix, B.; Jacobs, K.A.; Bowles, M.L. Two decades of low-severity prescribed fire increases soil nutrient availability in Midwestern, USA oak (Quercus) forest. Geoderma 2012, 183, 89-91. [CrossRef]

38. Qasim, S.; Gul, S.; Shah, M.H.; Hussain, F.; Ahmad, S.; Islam, M.; Rehman, G.; Yaqoob, M.; Shah, S.Q. Influence of grazing exclosure on vegetation biomass and soil quality. Int. Soil Water Conserv. Res. 2017, 5, 62-68. [CrossRef]

39. Shakesby, R.A.; Bento, C.P.M.; Ferreira, C.S.S.; Ferreira, A.J.D.; Stoof, C.R.; Urbanek, E.; Walsh, R.P.D. Impacts of prescribed fire on soil loss and soil quality: An assessment based on an experimentally-burned catchment in central Portugal. Catena 2015, 128, 278-293. [CrossRef]

40. Roaldson, L.M.; Johnson, D.W.; Miller, W.W.; Murphy, J.D.; Walker, R.F.; Stein, C.M.; Glass, D.W. Prescribed fire and timber harvesting effects on soil carbon and nitrogen in a pine forest. Soil Sci. Soc. Am. J. 2014, 78, S48-S57. [CrossRef]

41. Blankenship, B.A.; Arthur, M.A. Soil nutrient and microbial response to prescribed fire in an oak-pine ecosystem in eastern Kentucky. In Proceedings of the 12th Central Hardwood Forest Conference, Lexington, KY, USA, 1-2 March 1999; Stringer, J., Loftis, D., Eds.; Gen. Tech. Rep. SRS 24. USDA: Asheville, NC, USA, 1999; pp. 39-50.

42. Canals, R.M.; Pedro, J.; Rupérez, E.; San Emeterio, L. Nutrient pulses after prescribed Winter fires and preferential patterns of $\mathrm{N}$ uptake may contribute to the expansion of B rachypodium pinnatum (L.) P Beauv. in highland grasslands. Appl. Veg. Sci. 2014, 17, 419-428. [CrossRef]

43. Bowen, G.D.; Danso, S. Investigación sobre el nitrógeno en los cultivos perennes. OIEA Boletín 1987, 2, 5-8.

44. McNabb, D.H.; Cromack, K., Jr. Effects of prescribed fire on nutrients and soil productivity. In Natural and Prescribed Fire in Pacific Northwest Forests; Walstad, J.D., Radosevich, S.R., Sandberg, D.V., Eds.; Oregon State University Press: Corvallis, OR, USA, 1990; pp. 125-141.

45. Afif, E.; Oliveira, P. Efectos del fuego prescrito sobre el matorral en las propiedades del suelo. Investigaciones Agrarias. Sistema de Recursos Forestales 2006, 15, 262-270. 
46. McKee, W.H. Changes in Soil Fertility Following Prescribed Burning on Costal Pine Sites; United States Department of Agriculture Forest Service Research Paper SE-234; Southern Forest Experiment Station: Asheville, NC, USA, 1982.

47. Aarons, S.R.; Hosseini, H.M.; Dorling, L.; Gourley, C.J.P. Dung decomposition in temperate dairy pastures. II contribution to plant-available soil phosphorus. Aust. J. Soil Res. 2004, 42, 115-123. [CrossRef]

48. Sharpley, A.; Moyer, B. Phosporous forms in manure and compost and their release during simulated rainfall. J. Environ. Qual. 2000, 29, 1462-1469. [CrossRef]

49. Stavi, I.; Ungar, E.D.; Lavee, H.; Sarah, P. Grazing-induced spatial variability of soil bulk density and content of moisture, organic carbon and calcium carbonate in a semi-arid grassland. Catena 2008, 75, 288-296. [CrossRef]

50. INIA (Instituto Nacional de Investigación y Tecnología Agraria y Alimentaria). Interpretación de Análisis de Suelos; Serie Actas 4; INIA: Madrid, Spain, 2016; pp. 10-14.

51. Espinoza, L.; Slaton, N.; Mozaffari, M. Cómo Interpretar Los Resultados de Los Análisis de Suelos; Division of Agriculture Research \& Extension, University of Arkansas System: Little Rock, AR, USA, 2007; Available online: https://www.uaex.edu/publications/PDF/FSA-2118SP.pdf (accessed on 15 May 2019).

52. Sela, G. Guía de Interpretación de Análisis de Suelos; Smart Fertilizer Management: London, UK, 2018 ; pp. 1-4.

53. Landon, S. Introducción al análisis de suelos; CIAT: Cali, Colombia, 1983.

54. AQM. Available online: http://aqmlaboratorios.com (accessed on 5 June 2018).

(C) 2019 by the authors. Licensee MDPI, Basel, Switzerland. This article is an open access article distributed under the terms and conditions of the Creative Commons Attribution (CC BY) license (http://creativecommons.org/licenses/by/4.0/). 